
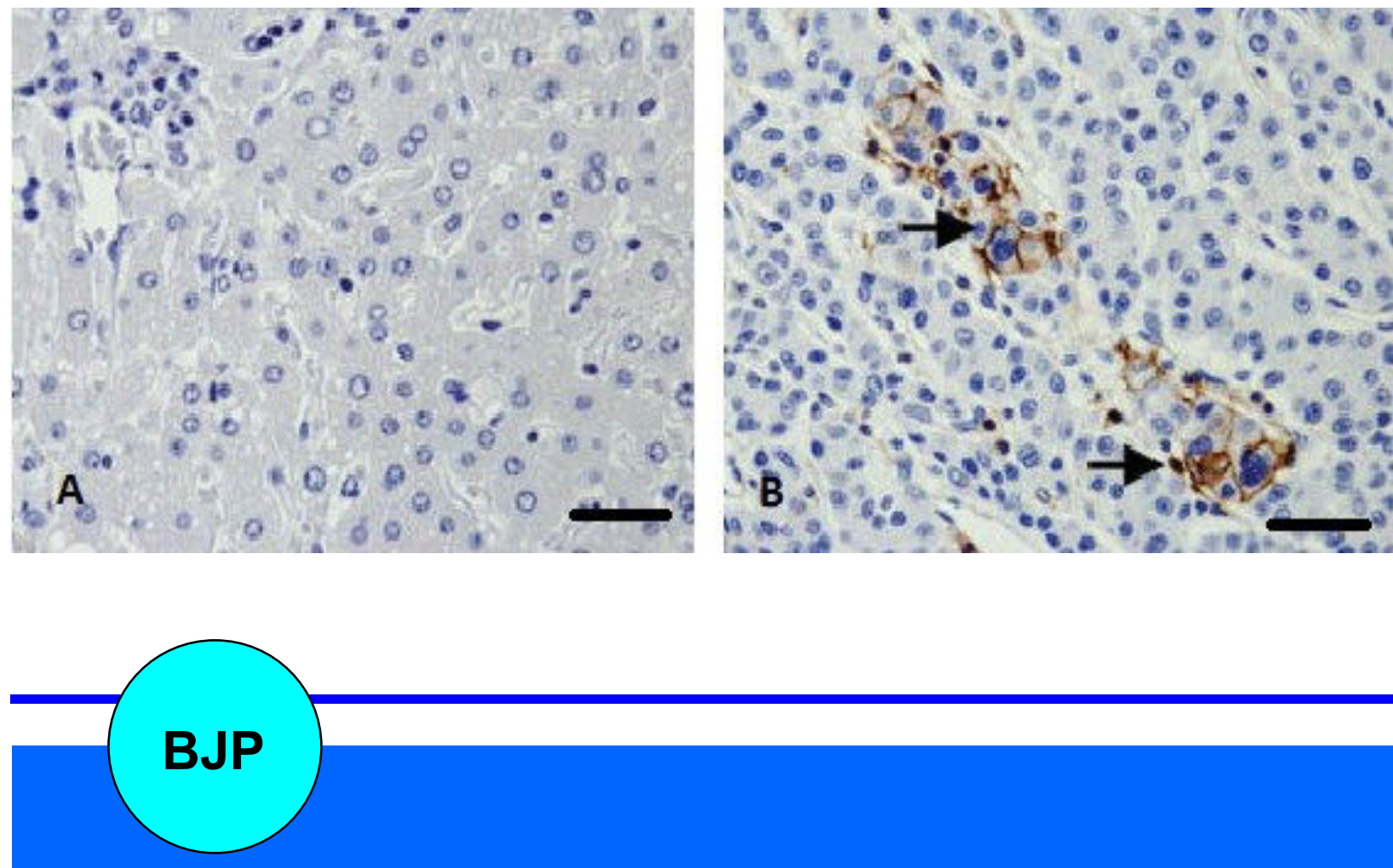

Bangladesh Journal of Pharmacology

Research Article

Role of microRNA miR-34a in liver cancer stem cells 
Abstracted/indexed in Academic Search Complete, Asia Journals Online, Bangladesh Journals Online, Biological Abstracts, BIOSIS Previews, CAB Abstracts, Current Abstracts, Directory of Open Access Journals, EMBASE/Excerpta Medica, Google Scholar, HINARI (WHO), International Pharmaceutical Abstracts, Open J-gate, Science Citation Index Expanded, SCOPUS and Social Sciences Citation Index;

ISSN: $1991-0088$

\section{Role of microRNA miR-34a in liver cancer stem cells}

\section{Lu-Lu Gong1, Shu-Li Yang², Guo-Feng Zhang', Jia-Cheng Wu1 and Rui-Xin Lin¹}

${ }^{1}$ Department of Hepato-Biliary-Pancreatic Surgery, The Second Hospital of Jilin University, Changchun 130 041, P. R. China; ${ }^{2}$ Department of Obstetrics and Gynecology, The Second Hospital of Jilin University, Changchun 130041, P. R. China.

\begin{tabular}{|lr|}
\hline Article Info & \\
\hline Received: & 14 September 2015 \\
Accepted: & 9 October 2015 \\
Available Online: & 20 March 2016 \\
DOI: 10.3329/bjp.v11i2.24975 & \\
& \\
Cite this article: & \\
Gong LL, Yang SL, Zhang GF, Wu JC, \\
Lin RX. Role of microRNA miR-34a in \\
liver cancer stem cells. Bangladesh J \\
Pharmacol. 2016; 11: 333-36.
\end{tabular}

\section{Abstract}

The present study focuses on the role of microRNA miR-34a in liver cancer stem cells. Liver tissue samples were collected from the control and liver cancer patients. Immunohistochemistry experiment with CD90 antibodies suggests that the liver cancer stem cells were present in the liver cancer tissue samples. Interestingly, flow cytometry analysis followed by qRT-PCR confirmed that the $\mathrm{CD} 90^{+}$cells also called as liver cancer stem cells shows expression of miR-34a at the levels of $30-80 \%$, when compared with that of normal liver tissue samples. The present study concludes that the liver cancer stem cells shows high expression of miR-34a, which is the important target unique to liver cancer stem cells in order to design liver cancer stem cellsspecific therapies.

\section{Introduction}

Liver cancer is the fifth most common cancer in the world (Yang et al., 2008). Cancer stem cells (CSCs) perform the tumor-initiating capability and have the ability to self-renew in most cancers. In short, like normal stem cells, CSCs have the properties of self renewal and multi-differentiation, to reconstitute tumors. It was reported that the CSCs are involved in tumor recurrence and tumor metastasis (Visvader and Lindeman, 2008). In contrast, it was identified and proved that the following cancers have CSCs, namely breast cancer (Al-Hajj et al., 2003; Ponti et al., 2005), gastric (Houghton et al., 2004), leukemia, glioblastoma (Hemmati et al., 2003; Singh et al., 2003; Singh et al., 2004), prostate (Collins et al., 2005; Richardson et al., 2004), lung (Kim et al., 2005) and colon cancer (O'Brien et al., 2007; Ricci-Vitiani et al., 2007). At the same time, it is very difficult to under-stand the characters of CSCs. Interestingly, it was reported that the normal stem cells shows common properties with CSCs (Burkert et al., 2006; Pardal et al., 2003; Reya et al., 2001). But it is not well documented regarding the key molecular mechanism in the context of microRNAs.

It was reported that more than $98 \%$ of non-coding DNAs (commonly called as 'junk' DNAs) are transcribed and known as non-coding RNAs (ncRNAs), which are divided into two categories namely, short ncRNAs and long ncRNAs (lncRNAs). The role and function of this RNAs remains unclear, and their relevance to disease is not understood. Rather, the short ncRNAs perform following specific functions such as modulation of alternative splicing, chromatin remodeling and RNA metabolism. In contrast, other types of short RNA called microRNAs, which are involved in various signaling and regulatory functions in the cells. It is essential to identify the signaling and regulatory mechanisms that are unique to liver CSCs in order to design liver CSC-specific therapies, which are needed for the current era. The molecular profile of microRNAs is important to target the functional aspects of liver CSCs. The present research focuses on the role of microRNA miR-34a in liver cancer stem cells. 


\section{Materials and Methods \\ Patients and sample collection}

Twenty one patients were included in the study. Liver biopsy was collected from the patients and stored in $80^{\circ} \mathrm{C}$ deep for RNA isolation and histology techniques. All biopsy tumor specimens were confirmed to contain $>90 \%$ tumor cells by experienced pathologists. Liver donors were used as controls.

\section{Immunohistochemistry}

Liver tissue samples were collected from the control and liver cancer patients and subjected to immunohistochemistry. Liver tissues samples were formalinfixed and paraffin-embedded using standard protocol. The tissue sections $(7 \mu \mathrm{m})$ were deparaffinized and hydrated. Antigens were retrieved by tri-sodium citrate treatment ( $\mathrm{pH}$ 6.0). Endogenous peroxides and nonspecific immune staining were blocked by hydrogen peroxide and normal serum, respectively. The sections were then incubated overnight at $4^{\circ} \mathrm{C}$ with monoclonal anti-CD90 antibody. After incubation with primary antibody, tissue sections were washed and incubated with secondary antibodies conjugated with HRP. The washed slides were developed with DAB substrate. The prepared slides were counterstained, mounted with DPX and observed under a microscope.

\section{Flow cytometry analysis}

Isolated cells from liver tumor tissues along with control were labeled with the anti-human antibodies PE -CD90, (BD Biosciences Pharmingen, USA) and detected in a FACS Calibur (Becton Dickinson Immunocytometry Systems, USA). Appropriate irrelevant antibodies (isotypes) were used as controls for the flow cytometry experiments.

\section{RNA extraction}

Total RNA was extracted from the two categories of samples, namely liver cancer and normal liver tissue samples using TRIzol reagent method (Invitrogen) as per the manufacturer's instruction. Liver cancer samples were homogenized with TRIzol reagent using $1 \mathrm{~mL}$ per 50 to $100 \mathrm{mg}$ tissues. RNA concentrations and quality were determined by NanoDrop, and the RNA integrity was assessed by agarose gel electrophoresis. The isolated RNA samples were used for qRT-PCR analysis.

\section{Quantification of miR-34a levels using qRT-PCR}

The microRNA, miR-34a level were analyzed using TaqMan MicroRNA assays. Total RNA was isolated from the CD90+ sorted cells followed by recovering of small RNA fractions ( $<200$ nucleotides) using the mirVANA PARIS miRNA isolation kit (Ambion). The integrity of the RNA was checked using NanoDrop at the absorbance of $260 \mathrm{~nm}$. qRT-PCR was performed with the threshold cycle $(\mathrm{Ct})$ as the fractional cycle number at which fluorescence exceeds the fixed thres- hold of 0.2. Quantitative miR-34a expression were analyzed using $\mathrm{dCt}$ (the $\mathrm{Ct}$ value normalized to internal 'housekeeping' miRNAs such as miR-24 and miR-103) and ddCt (difference between the $\mathrm{dCt}$ of positive population and that of the negative population) values for each of the miRNAs. The percentage of expression was calculated using the formula 2-ddCt. Total RNA with the concentration of $10 \mathrm{ng}$ was used to measure the miR-34a.

\section{Results}

\section{Immunohistochemistry analysis}

Liver cancer tissue samples along with control were subjected to immunohistochemistry to identify, whether the expression of $\mathrm{CD} 0^{+}$is present in the collected liver cancer tissue samples. $\mathrm{CD}^{+} 0^{+}$antibody was used for immunohistochemistry, which was the molecular marker for the liver cancer cells and as well as liver cancer stem cells. Figure $1 \mathrm{~A}$ shows no expression of $\mathrm{CD}^{+} 0^{+}$cells, whereas Figure 1B shows the CD90+ cells. All the liver cancer tissue samples shows the CD90+ cells, but normal liver tissue sample have no expression of $\mathrm{CD}^{+}{ }^{+}$cells. The immunohistochemistry results suggested that the OSCC tissue samples has the CD90+ cells, which implies that the sample contain liver cancer cells and obviously liver cancer stem cells.

\section{Flow cytometry analysis}

Sorting of $\mathrm{CD}^{+} 0^{+}$cells was essential for further studies, which was achieved by flow cytometry. The CD90+ sorted cells from normal liver tissue sample and liver cancer tissue sample were shown in Figure 2. It was found that the liver cancer tissue sample has CD90+ sorted cells other than the control. The data correlates with the immunohistochemistry analysis and reveals that the sample obtained from the cancer patients contain liver cancer cells and obviously liver cancer stem cells. In addition, the data of immunohistochemistry was cross checked and validated by the flow cytometry analysis.

\section{qRT-PCR analysis}

Expression pattern of miR-34a in $\mathrm{CD}^{+} 0^{+}$sorted cells was achieved by qRT-PCR experiments. The data shows the expression profile of the miR-34a in the normal liver tissue samples as well as liver cancer tissue samples. Figure 3 confirms that the miR-34a was expressed highly in CD90+ cells.

\section{Discussion}

In this study, CD90+ cells of liver cancer tissue samples show high expression of miR-34a. Though, CD90 ${ }^{+}$cells are cancer stem cells, interestingly, which have the high expression pattern of miR-34a. 


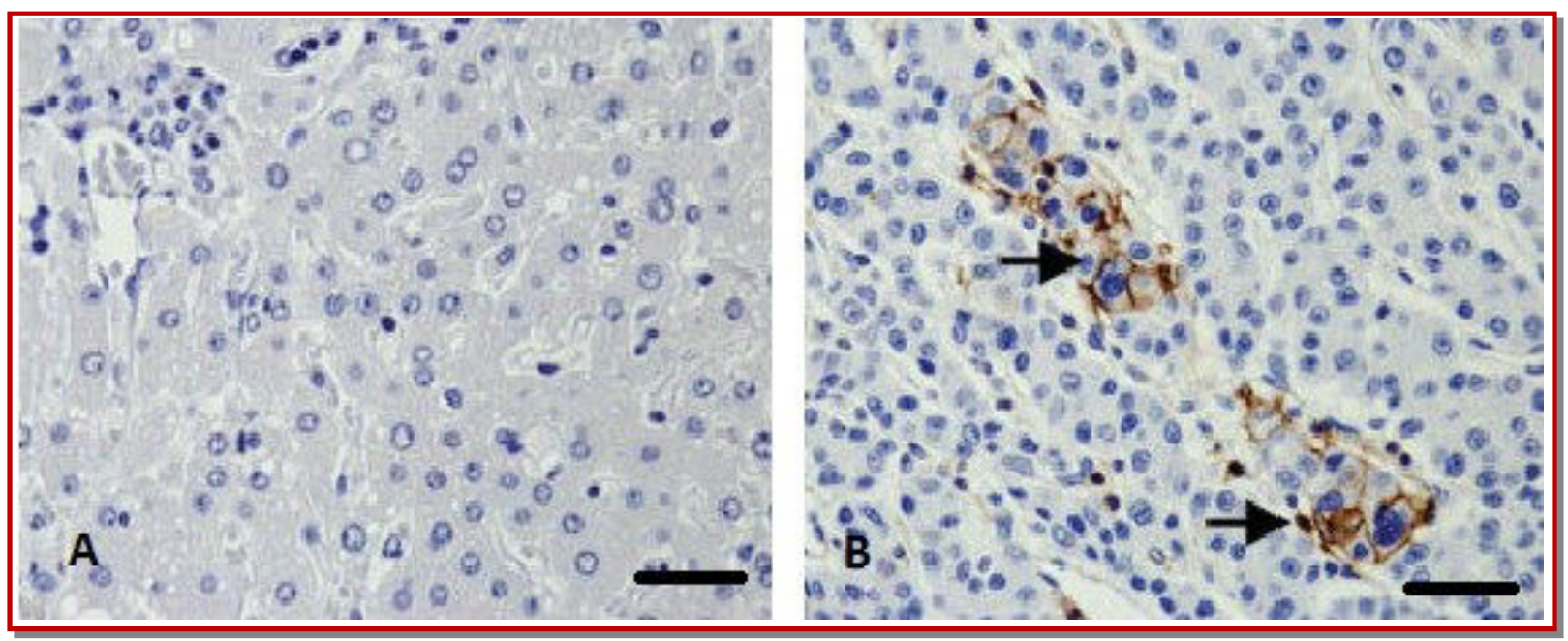

Figure 1: Immunohistochemistry analysis. A. Normal liver tissue samples show no $\mathrm{CD}^{+} 0^{+}$cells. B. Liver cancer tissue samples show $\mathrm{CD} 90^{+}$cells as mentioned in the figure with arrow mark. The $\mathrm{CD} 90^{+}$cells are brown in color after staining it with $\mathrm{DAB}$

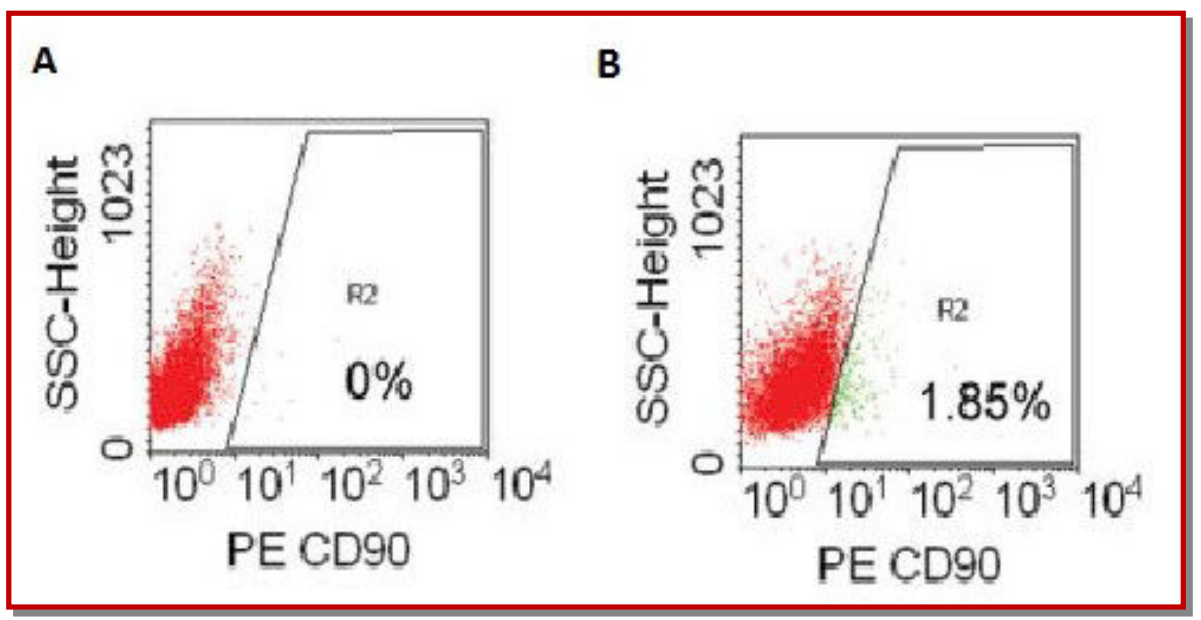

Figure 2: Flow cytometry analysis. Liver cancer tissue samples and normal liver tissue samples were subjected to cell sorting with $\mathrm{CD} 90^{+}$cells. A. Cells from normal liver tissue samples show $0 \%$ of $\mathrm{CD} 90^{+}$cells. B. Cells from liver cancer tissue samples show $1.85 \%$ of $\mathrm{CD} 90^{+}$cells

It was reported that $\mathrm{CD} 90^{+}$human prostate cancer cells expressed miR-34a at levels of $\sim 25-70 \%$. In the present study, the $\mathrm{CD}^{+} 0^{+}$cells also called as liver CSCs shows expression of miR-34a at the levels of $30-80 \%$. It was reported that the $\mathrm{CD} 45^{+}$and $\mathrm{CD} 90^{+}$cells were used for effective identification of liver CSCs (Yang et al., 2008), but present study reveals that in future miR-34a expression may be used as marker to identify the liver cancer stem cells.

It is interesting that the expression of miR-34a is high in liver cancer tissue samples, especially in CD90+cells, when compared with that of normal liver tissue samples.

\section{Conclusion}

The liver CSCs shows high expression of miR-34a, which is the important target unique to liver CSCs in order to design liver CSC-specific therapies.

\section{Ethical Issue}

All the tissue and blood samples were obtained from consenting patients, and the study was approved by the Institutional Review Board.

\section{Acknowledgement}

The authors were thankful to the patients and the ethical committee for the successful completion of the project. The Project was supported by the Natural Science Foundation of Jilin Province, China (Grant No.20150101162JC ).

\section{References}

Al-Hajj M, Wicha MS, Benito-Hernandez A, Morrison SJ, 


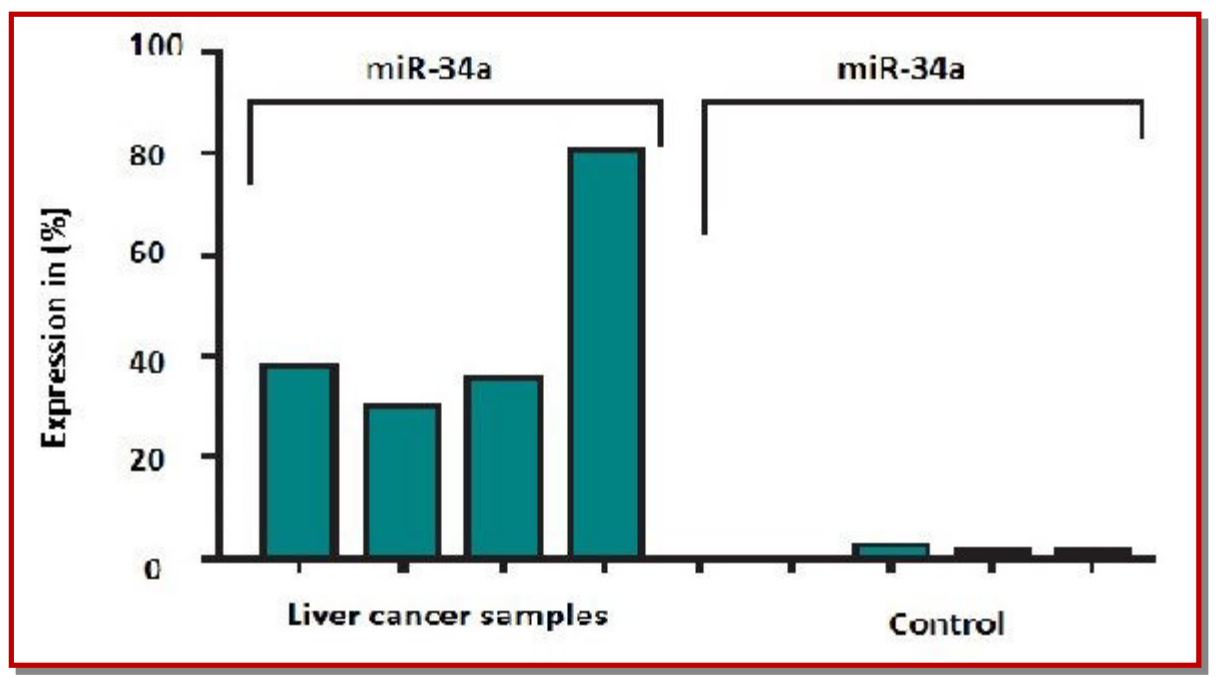

Figure 3: qRT-PCR analysis. RNA isolated from the CD90 sorted cells of liver cancer and normal tissues were subjected to qRTPCR. Liver CSCs shows miR-34a expression in the all the liver cancer tissue samples when compared with that of control

Clarke MF. Prospective identification of tumorigenic breast cancer cells. Proc Nat Acad Sci. 2003; 100: 3983-88.

Burkert J, Wright NA, Alison MR. Stem cells and cancer: An intimate relationship. J Pathol. 2006; 209: 287-97.

Collins AT, Berry PA, Hyde C, Stower MJ, Maitland NJ. Prospective identification of tumorigenic prostate cancer stem cells. Cancer Res. 2005; 65: 10946-51.

Hemmati HD, Nakano I, Lazareff JA, Masterman-Smith M, Geschwind DH, Bronner-Fraser M, Kornblum HI. Cancerous stem cells can arise from pediatric brain tumors. Proc Nat Acad Sci USA. 2003; 100: 15178-83.

Houghton J, Stoicov C, Nomura S, Rogers AB, Carlson J, Li H, Cai X, Fox JG, Goldenring JR, Wang TC. Gastric cancer originating from bone marrow-derived cells. Science 2004; 306: 1568-71.

Kim CF, Jackson EL, Woolfenden AE, Lawrence S, Babar I, Vogel S, Crowley D, Bronson RT, Jacks T. Identification of bronchioalveolar stem cells in normal lung and lung cancer. Cell 2005; 121: 823-35.

O'Brien CA, Pollett A, Gallinger S, Dick JE. A human colon cancer cell capable of initiating tumour growth in immunodeficient mice. Nature 2007; 445: 106-10.

Pardal R, Clarke MF, Morrison SJ. Applying the principles of stem-cell biology to cancer. Nat Rev Cancer. 2003; 3: 895-902.

Ponti D, Costa A, Zaffaroni N, Pratesi G, Petrangolini G,
Coradini D, Pilotti S, Pierotti MA, Daidone MG. Isolation and in vitro propagation of tumorigenic breast cancer cells with stem/progenitor cell properties. Cancer Res. 2005; 65: 5506-11.

Reya T, Morrison SJ, Clarke MF, Weissman IL. Stem cells, cancer, and cancer stem cells. Nature 2001; 414: 105-11.

Ricci-Vitiani L, Lombardi DG, Pilozzi E, Biffoni M, Todaro M, Peschle C, De Maria R. Identification and expansion of human colon-cancer-initiating cells. Nature 2007; 445: 111-15.

Richardson GD, Robson CN, Lang SH, Neal DE, Maitland NJ, Collins AT. CD133, a novel marker for human prostatic epithelial stem cells. J Cell Sci. 2004; 117: 3539-45.

Singh SK, Clarke ID, Terasaki M, Bonn VE, Hawkins C, Squire J, Dirks PB. Identification of a cancer stem cell in human brain tumours. Cancer Res. 2003; 63: 5821-28.

Singh SK, Hawkins C, Clarke ID, Squire JA, Bayani J, Hide T, Henkelman RM, Cusimano MD, Dirks PB. Identification of human brain tumour initiating cells. Nature 2004; 432: 396401.

Visvader JE, Lindeman GJ. Cancer stem cells in solid tumours: Accumulating evidence and unresolved questions. Nature Rev Cancer. 2008; 8: 755-68.

Yang ZF, Ngai P, Ho DW, Yu WC, Ng MN, Lau CK, Li ML, Tam KH, Lam CT, Poon RT, Fan ST. Identification of local and circulating cancer stem cells in human liver cancer. Hepatology 2008; 47: 919-28.

\footnotetext{
Author Info

Rui-Xin Lin (Principal contact)

I e-mail: linruixin59@hotmail.com
} 


\section{Your feedback about this paper}

1. Number of times you have read this paper 0

2. Quality of paper Click

3. Your comments

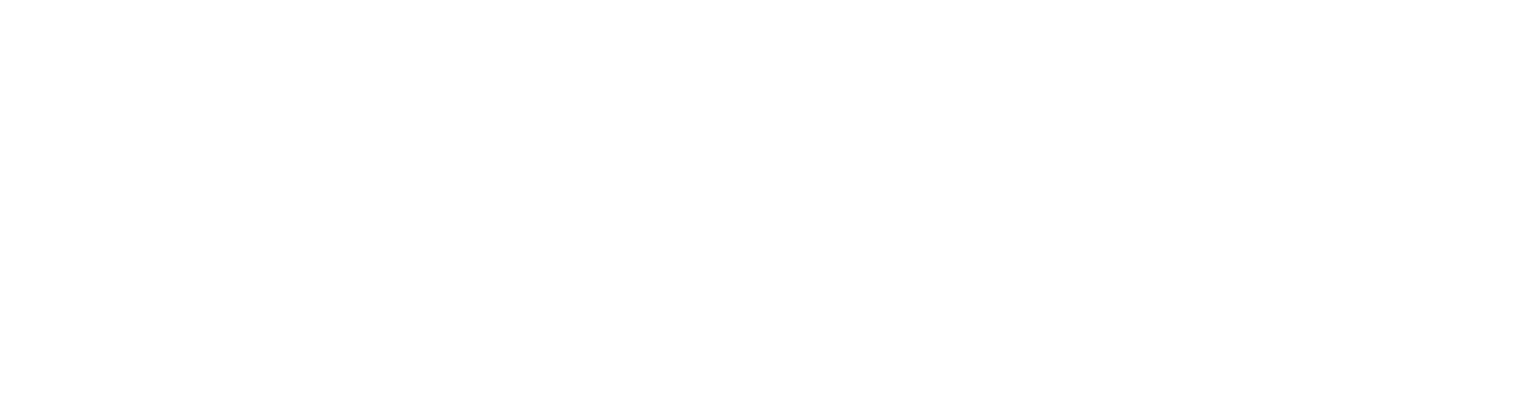

